\title{
Physical and chemical quality, biodiversity, and thermodynamic prediction of adhesion of bacterial isolates from a water purification system: a case study
}

\author{
Roberta Barbosa Teodoro Alves ${ }^{*}$, Nélio José de Andrade ${ }^{1}$, Edimar Aparecida Filomeno Fontes ${ }^{1}$, \\ Patrícia Campos Bernardes ${ }^{2}$, Antônio Fernandes de Carvalho ${ }^{1}$
}

\author{
${ }^{1}$ Food Technology Department, Federal University of Viçosa, Viçosa, MG, Brazil, ${ }^{2}$ Food Engineering Departmen, Federal \\ University of Espírito Santo, Alegre, ES, Brazil
}

\begin{abstract}
The objective of this study was to evaluate the quality of water purification system and identify the bacteria this system, predict bacterial adherence according to the hydrophobicity of these microorganisms and of the polypropylene distribution loop for purified water. The assessment of drinking water that supplies the purification system allowed good-quality physical, chemical, and microbiological specifications. The physicochemical specifications of the distributed purified water were approved, but the heterotrophic bacteria count was higher than allowed $\left(>2 \log \mathrm{CFU} \mathrm{mL}^{-1}\right)$. The sanitation of the storage tank with chlorine decreased the number of bacteria adhered to the surface ( 4.34 cycles log). By sequencing of the 16SrDNA genes, six species of bacteria were identified. The contact angle was determined and polypropylene surface and all bacteria were considered to be hydrophilic, and adhesion was thermodynamically unfavorable. This case study showed the importance of monitoring the water quality in the purified water systems and the importance of sanitization with chemical agents. The count of heterotrophic bacteria on the polypropylene surface was consistent with the predicted thermodynamics results because the number

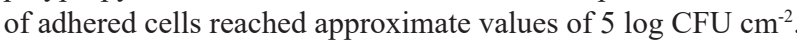

Uniterms: Purified water/quality. Purified water/adhesion. Purified water/bacterial biodiversity. Prediction thermodynamics. Hydrophobicity.

\section{INTRODUCTION}

To become suitable for use in the laboratory or in industry pharmaceutical, water should be treated to eliminate its contaminants, creating purified water. The entire process of production, storage, and distribution should be properly validated and monitored for significant physical-chemical and microbiological characteristics.

Monitoring water purification systems is critical to obtain water with good microbiological and physicalchemical characteristics, and the assessment of water should meet the technical recommendations and the requirements of legislation. The quality of purified water is an important concern for use in analytical laboratories,

\footnotetext{
*Correspondence: R. B. T. Alves. Departamento de Tecnologia de Alimentos. Universidade Federal de Viçosa. Av. P.H. Rolfs s/n, Campus Universitário, CEP: 36570-000, Viçosa, Minas Gerais, Brasil. E-mail: rob_pharma@hotmail.com
}

in the pharmaceutical and medical fields, and in a wide variety of industries.

As a fundamental guideline, potable water is the starting point for any process of purification (FDA, 1986). The physical-chemical quality is related to the fundamental assessment of the water for alkalinity, conductivity, residual free chlorine, hardness, ISL (Langelier Saturation Index), $\mathrm{pH}$, and silica content.

Although purified water contains small amounts of organic molecules, a group of microorganisms known as oligotrophes has adapted to these conditions (Ridgway, Rigby, Argo, 1984; McFeters et al., 1993; ChristieOleza et al., 2012; Zhang, Huang, Liu, 2013). However, there is little research on the microbial ecology of water purification systems. Equipment surfaces of the systems are also susceptible to adhesion and biofilms can therefore be established as a source of viable microorganisms in purified water (Penna, Martins, Mazzola, 2002). It was reported that purified water, even with total organic carbon 
concentrations less than $0.5 \mathrm{mg} \cdot \mathrm{L}^{-1}$, supported biofilm formation (Florjanič, Kristl, 2011).

In the storage and distribution of water, bacterial contamination is one of the most persistent problems because microorganisms have the ability to adapt to a nutrient-poor environment, such as water purification systems (Clinical and Laboratory Standards Institute, 2006).

Chemical cleaning is important to reduce the contamination of these water purification systems. These chemicals may be used alone or in combination (Sohrabi et al., 2011). Thus, the cleaning procedure for purified water equipment must be regulated to avoid the formation of bacterial biofilm on tank walls, equipment, and connections.

An investigation of the microbial diversity of a water purification system is required and such an investigation can assist in choosing suitable pre-treatment and more effective cleaning strategies (Bereschenko et al., 2010). Among the methodologies available for microbial identification, sequence analysis of ribosomal RNA 16S rDNA has been widely used to identify bacterial species and perform taxonomic studies (Baker, Smith, Cowan, 2003; Chakravorty et al., 2007; Kim, Morrison, Yu, 2011).

In addition to microbial diversity, knowledge related to the bacterial adhesion mechanism and the formation of biofilms on the surfaces is important. The adhesion of bacteria is a complex process that is affected by many factors, such as the physicochemical characteristics of bacteria (hydrophobicity, surface charge). The characteristics of the surfaces of pipes can also contribute to the adhesion of bacteria and influence biofilm formation, including the surface properties of the material (surface charge, hydrophobicity, roughness and texture). A better understanding of the relationship between adhesion and biofilm formation is important for the development of effective control strategies in the early stages of biofilm development (Simões, Simões, Vieira, 2010).

Different approaches have been used to describe and predict bacterial adhesion to surfaces. The adhesion can be explained by the Derjaguin-Landau-Verwey-Overbeek (DLVO) theory (Van Loosdrecht et al., 1990), based on thermodynamics (Absolom et al., 1983; Busscher et al., 1984), and by the extended DLVO theory (XDLVO) (Van Oss, 1989; Meinders, Van Der Mei, Busscher, 1995). The latter integrates thermodynamic aspects with the DLVO theory. However, important biological factors have been largely ignored in these models.

The objective of this study was to evaluate the quality of drinking water that feeds a purification system (in operation for two years) and the water obtained from this system. This study also sought to identify bacterial strains present in the water and to predict bacterial adherence according to the hydrophobicity of these microorganisms and of the polypropylene distribution loop for purified water.

\section{MATERIAL AND METHODS}

\section{Water sampling and procedures}

Water samples from five points of a purification system located in a laboratory of the Federal University of Viçosa, MG, Brazil were collected in the period from May-August 2013 (Figure 1). Physico-chemical and microbiological quality was evaluated in the following collection points: drinking water that feeds the system (point 1), purified water (point 2) and water stored and distributed in three collection points for use in laboratories (points 3, 4 and 5). For microbiological analyses, before each water sample was collected, each sampling point was sanitized with $70 \%$ ethanol (v/v), and the first aliquots of water were dispensed for $1 \mathrm{~min}$. Water samples were collected in sterilized glass containers and analyzed within a maximum of $24 \mathrm{~h}$.

\section{Physico-chemical and microbiological quality of drinking and purified water}

The parameters analyzed and the methods and the instruments used are presented, respectively. The drinking water that feeds the purification system was analyzed daily for 40 days for the following parameters: turbidity (NTU, turbidimeter $\mathrm{HACH} 2100)$; temperature $\left({ }^{\circ} \mathrm{C}\right)$ (APHA); conductivity $\left(\mu \mathrm{S} \mathrm{cm}^{-1}\right)$ (APHA, Hanna); pH (APHA, pHmeter MA PA210p model); hardness $\left(\mathrm{mg} \mathrm{L}^{-1}\right.$ as $\left.\mathrm{CaCO}_{3}\right)$ (titration, APHA); calcium ( $\mathrm{mg} \mathrm{l}^{-1}$ as $\mathrm{Ca}^{2+}$ ) (titration, APHA); alkalinity ( $\mathrm{mg} \mathrm{L}^{-1}$ as $\mathrm{CaCO}_{3}$ ) (titration, APHA), free residual chlorine ( $\mathrm{mg} \mathrm{l}^{-1}$ as CRL) (colorimetric, APHA, Lamotte I200 model spectrophotometer); total dissolved solids ( $\left.\mathrm{mg} \mathrm{L}^{-1}\right)$ (APHA, plate heater, brand DigTech); silica (mg L-1 as $\mathrm{SiO}_{2}$ ) (APHA, Biospectro spectrophotometer, SP-22), Langelier saturation index (NING; NETWIG, 2002) and counts of heterotrophic bacteria (pour plate, R2A agar Himedia ${ }^{\circledR}$, incubation at $35^{\circ} \mathrm{C} 72 \mathrm{~h}$ ). The methods are described in the Standard Methods for the Examination of Water and Wastewater (American Public Health Association, 2005).

The water obtained from the purifying system was also monitored daily for 40 days for temperature $\left({ }^{\circ} \mathrm{C}\right)$, conductivity $\left(\mu \mathrm{S} \mathrm{cm}^{-1}\right), \mathrm{pH}$ ( $\mathrm{pH}$ meter model PA210p MA), silica ( $\mathrm{mg} \mathrm{l}^{-1}$ as $\mathrm{SiO}_{2}$ ) (Biospectro spectrophotometer, 


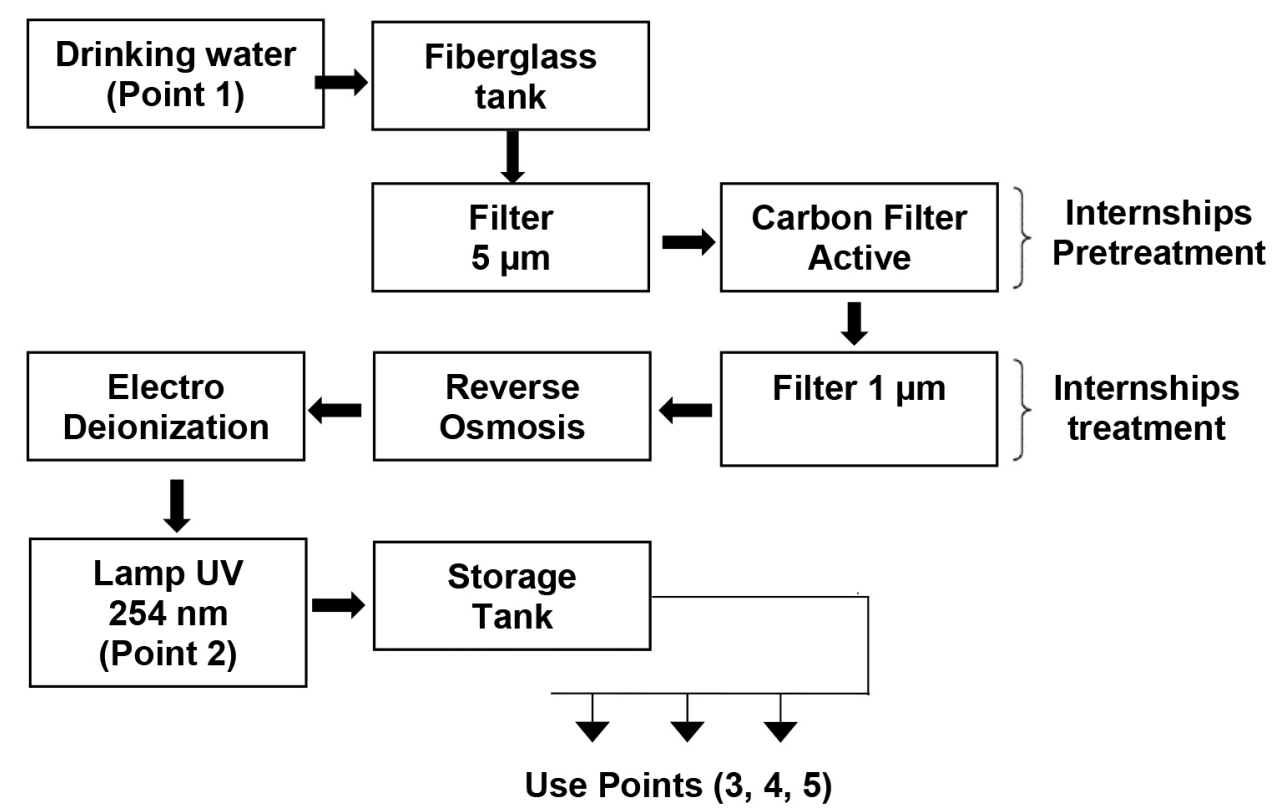

FIGURE 1 - Purification system studied in this work. Directing the flow of water indicated by the arrows.

SP-22) and heterotrophic bacteria count (filtration and membrane technique, R2A agar $\left(\right.$ Himedia $\left.^{\circledR}\right)$ after incubation at $35^{\circ} \mathrm{C}$ for $72 \mathrm{~h}$ ). The methodologies were proposed by British Pharmacopoeia (2009).

\section{Evaluation of the cleaning procedure of the water purification system}

The drinking water tank that feeds the purification system was sanitized (Public Health Protection, 2009). After this procedure, the drinking water was monitored for heterotrophic bacteria count for a minimum period of 20 days of sampling.

The storage e tank and water distribution loop were sanitized with a sodium hypochlorite solution at a concentration of $500 \mathrm{mg} \mathrm{L}^{-1}$ total residual chlorine as $\mathrm{Cl}_{2}, \mathrm{pH} 8$ and a contact time of $120 \mathrm{~min}$. To evaluate the efficiency of the sanitizing procedure, the swab technique was applied to the surface of the storage tank and the pipes of the distribution system. After sanitization, distributed purified water was monitored by heterotrophic bacterial count daily for 20 days.

\section{Isolation of bacteria from the water purification system and DNA extraction from the isolates}

Volumes of $1 \mathrm{~mL}$ of water samples collected at the points of the purification system were inoculated on the surfaces of petri dishes containing R2A agar and incubated at $35{ }^{\circ} \mathrm{C}$ (American Society for Testing and Material,
1991; British Pharmacopoeia, 2009). Colonies grown in this medium with different types of morphology and colors were isolated and subcultured in BHI (Brain Heart Infusion) (Fluka Analytical ${ }^{\circledR}$ ). The pure cultures of the various bacteria were kept at $-18{ }^{\circ} \mathrm{C}$ in microcentrifuge tubes containing brain heart infusion (BHI) and glycerol (80:20).

Extraction of the isolated DNA was performed with the Wizard ${ }^{\circledR}$ Genomic DNA Purification kit (Promega, USA) following the extraction protocol. The quality of extracted DNA was analyzed and quantitated by reading on a NanoDrop-100 spectrophotometer (Thermo Scientific).

\section{$16 S$ rDNA amplification}

To determine the bacterial genera and species present in the purified water, the amplification of bacterial $16 \mathrm{~S}$ rRNA genes was performed with primers $27 \mathrm{~F}$ initiator 5-AGA GTT TGG TGA TCM CTC AG-3 and reverse 1378R 5-CGG TGT GTA CAA GGC GCC GGA $A C G 3$ (Sigma ${ }^{\circledR}$, USA), which gave rise to fragments of approximately $1500 \mathrm{bp}$. The reactions were performed in volumes of $25 \mu \mathrm{L}$ containing $2.5 \mu \mathrm{L}$ of $10 \mathrm{X}$ reagent Buffer (Sigma ${ }^{\circledR}$, USA), 200 M dNTPs (Promega ${ }^{\circledR}$, United States), 1 U Taq Polymerase (Sigma ${ }^{\circledR}$, USA) $0.1 \mu \mathrm{M}$ of each primer and approximately $80 \mathrm{ng}$ of total DNA.

The PCR reaction was performed in a thermocycler (Maxygene Axygen, USA). Amplification conditions followed the following protocol: 3 min denaturation at 94 
${ }^{\circ} \mathrm{C} ; 35$ cycles of amplification at $94{ }^{\circ} \mathrm{C}$ for $1 \mathrm{~min}$; annealing at $55^{\circ} \mathrm{C}$ for $1 \mathrm{~min}$ and extension at $72{ }^{\circ} \mathrm{C}$ for $2 \mathrm{~min}$ and $72{ }^{\circ} \mathrm{C}$ for $10 \mathrm{~min}$. Product formation was confirmed by electrophoresis of $3 \mu 1$ on a $1 \%(\mathrm{w} / \mathrm{v})$ agarose gel (Promega ${ }^{\circledR}$, United States) stained with ethidium bromide.

\section{Sequencing of the amplified product in the PCR}

The PCR products were bidirectionally sequenced with the primers and universal primers $27 \mathrm{~F}$ and $1378 \mathrm{R}$ from Macrogen Inc. (Seoul, South Korea) with the Model 3730XL sequencer (Applied Biosystems, USA).

The bidirectional sequences obtained were compared to their complementary strands, generating a consensus tape generated by DNA Baser program software 3.5.4 (http://www.dnabaser.com/index.html). The sequences obtained from each individual were subjected to comparative analysis with the database from the National Center for Biotechnology Information (NCBI) (http:// www.ncbi.nlm.nih.gov/) using the BLAST algorithm (Basic Local Alignment Search Tool).

Translation of the DNA sequence for amino acids from different isolates was performed using the BLASTN algorithm, which expresses a sequence of nucleotides to amino acids and is compared with the sequences deposited in the NCBI database. An agreement of at least $95 \%$ was assumed to confirm the specificity of the sequence.

\section{Measurement of the contact angle}

\section{Surface}

The surface hydrophobicity was evaluated after contact angle measurements using the approach described by Van Oss et al. (1989). The surfaces of the distribution loop material (polypropylene plates, Belfano brand, model tubelli 32) were subjected to analysis to determine the contact angles with three liquids of different polarities: water (Milli-Q), formamide (Bio LGC, Sao Paulo, Brazil) and $\alpha$-bromonaphthalene (Merck, Brazil). The contact angles were determined by the sessile drop method using a Krüss ${ }^{\circledR}$ brand goniometer, Easy Drop model (Hamburg, Germany).

\section{Microorganisms}

The measurement of the contact angles for different species of microorganism isolates was performed on a layer of vegetative cells using methodology described by Busscher et al. (1984). First, bacteria were grown twice in $30 \mathrm{~mL}$ of BHI broth (Fluka analytical ${ }^{\circledR}$ ) for 20 to $24 \mathrm{~h}$ to obtain a slurry of the active culture with approximately $1.0 \times$ $0^{7} \mathrm{CFU} \mathrm{mL} \mathrm{m}^{-1}$. After the active cultures were centrifuged at
$4100 \mathrm{x} g$ for $10 \mathrm{~min}$ at $4{ }^{\circ} \mathrm{C}$ (Eppendorf Centrifuge 5804R), the pellets were washed three times with phosphate- buffered saline (PBS) $0.1 \mathrm{~mol} \mathrm{l}^{-1}$. The cell mass was resuspended in $0.1 \mathrm{~mol} \mathrm{~L}^{-1} \mathrm{PBS}$ and deposited on a cellulose ester membrane filter $(0.45 \mu \mathrm{m}$ pore size and $47 \mathrm{~mm}$ diameter, Millipore $)$ in a filtration system using negative pressure. After filtration and avoiding dehydration of the cells, the membranes were placed in petri dishes containing previously prepared $1 \% \operatorname{agar}(\mathrm{w} / \mathrm{v})$ (Difco) and 10\% glycerol (v/v) Merck ${ }^{\circledR}$ ). The membranes with the cell layer were carefully cut to determine the contact angles with water, formamide and $\alpha$-bromonaphthalene.

\section{Determination of the total interfacial tension}

The total interfacial tension was determined by the sum of the apolar and polar components of the respective surfaces (Eq. 1).

$$
\gamma_{l}^{T O T}(1+\cos \theta)=2 \sqrt{\gamma_{s}^{L W} \gamma_{l}^{L W}}+2 \sqrt{\gamma_{s}^{-} \gamma_{l}^{+}}+2 \sqrt{\gamma_{s}^{+} \gamma_{l}^{-}}
$$

where $\gamma_{l}$ is the total interfacial tension of the liquid, $\gamma_{l}^{L W}$ is the interfacial tension of the interactions of the Lifshitzvan der Waals, $\gamma_{l}^{+}$is the interfacial tension of the electron acceptor component of the acid-base component, $\gamma_{l}^{-}$is the interfacial tension of the electron donor component of the acid-base component, $\theta$ is the contact angle, and $\mathrm{s}$ and 1 indicate surface and liquid, respectively.

The three components of the interfacial tension that are necessary to obtain the contact angle formed by three liquids of different polarities were determined. The amounts of polar liquid and nonpolar components used are shown in Table I (Van Der Mei, Bos, Busscher, 1998).

TABLE I - Values for interfacial tension of the components of the liquid at $25^{\circ} \mathrm{C}$

\begin{tabular}{lcccc}
\hline \multirow{2}{*}{ Liquid } & \multicolumn{4}{c}{ Interfacial tension $\left(\mathbf{m J ~ m}^{-2}\right)$} \\
\cline { 2 - 5 } & $\gamma_{l}^{\text {TOT }}$ & $\gamma_{l}^{L W}$ & $\gamma_{l}^{+}$ & $\gamma_{l}^{-}$ \\
\hline Water & 72.8 & 21.8 & 25.5 & 25.5 \\
a-bromonaphthalene & 44.4 & 44.4 & 0.0 & 0.0 \\
Formamide & 58.0 & 39.0 & 2.28 & 39.6 \\
\hline
\end{tabular}

The interfacial tension $\left(\gamma_{\mathrm{s}}^{\mathrm{TOT}}\right)$ is the result of the sum of the two components $\gamma_{\mathrm{s}}^{L W}$ and $\gamma_{\mathrm{s}}^{A B}$.

$$
\begin{aligned}
& \gamma_{s}^{L W}=11.1\left(1+\cos \theta_{B}\right)^{2} \\
& \gamma_{s}^{A B}=2 \sqrt{\gamma_{s}^{+} \times \gamma_{s}^{-}} \\
& \gamma_{s}^{T O T}=\gamma_{s}^{L W}+\gamma_{s}^{A B}
\end{aligned}
$$


where $\gamma_{s}^{L W}$ is the interfacial tension of the interactions of the Lifshitz-van der Waals forces, $\theta_{\mathrm{B}}$ is the contact angle obtained with $\alpha$-bromonaphthalene, $\gamma_{\mathrm{s}}^{A B}$ is the polar component of the Lewis acid-base interaction, $\gamma_{\mathrm{s}}{ }^{+}$is the interfacial tension of the electron acceptor component of the acid-base component, $\gamma_{s}^{-}$is the interfacial tension of the electron donor component of the acid-base component, and $\gamma_{\mathrm{s}}^{T O T}$ is the total interfacial tension of the surface.

\section{Free energy of the hydrophobic interaction $\Delta G_{\mathrm{SAS}}^{\mathrm{TOT}}$}

The total free energy of the interaction among molecules of the surface (s) immersed in water (w) was determined by the sum of the apolar and polar free energies of interaction, $\Delta \mathbf{G}_{\mathrm{SAS}}^{\mathbf{L W}}$ e $\Delta \mathbf{G}_{\mathrm{SAS}}^{\mathrm{AB}}$, respectively (Van Oss, 1995).

$$
\begin{aligned}
\Delta G_{S A S}^{T O T} & =\Delta G_{S A S}^{L W}+\Delta G_{S A S}^{A B} \\
\Delta G_{S A S}^{L W} & =-2 \cdot \sqrt{\gamma_{s}^{L W}-\gamma_{w}^{L W}} \\
\Delta G_{S A S}^{A B} & =-4\left(\sqrt{\gamma_{s}^{+} \gamma_{s}^{-}}+\sqrt{\gamma_{w}^{+} \gamma_{w}^{-}}-\sqrt{\gamma_{s}^{+} \gamma_{w}^{-}}-\sqrt{\gamma_{w}^{+} \gamma_{s}^{-}}\right)
\end{aligned}
$$

\section{Determination of the total free energy of adhesion $\left(\Delta G_{\text {adhesion }}\right)$}

Using the values of the components of the interfacial tension, it is possible to determine the $\Delta \mathrm{G}$ between two surfaces (microbial cells (b) and food surfaces (s)):

$\gamma_{b s}=\gamma_{b s}^{L W}+\gamma_{b s}^{A B}$

$\gamma_{b s}^{L W}=\gamma_{b}^{L W}+\gamma_{s}^{L W}-2 \sqrt{\gamma_{b}^{L W} \gamma_{s}^{L W}}$

$\gamma_{b s}^{A B}=2\left(\sqrt{\gamma_{b}^{+} \gamma_{b}^{-}}+\sqrt{\gamma_{s}^{+} \gamma_{s}^{-}}-\sqrt{\gamma_{b}^{+} \gamma_{s}^{-}}-\sqrt{\gamma_{b}^{-}} \gamma_{s}^{+}\right)$

When free energy is related to the interfacial tension, $\Delta \mathrm{G}_{\text {adhesion }}$ is then represented by the following:

$\Delta G_{\text {adhesion }}=\Delta G_{b l s}^{L W}+\Delta G_{b l s}^{A B}$

$\Delta G_{b l s}^{L W}=\gamma_{b s}^{L W}-\gamma_{b l}^{L W}-\gamma_{s l}^{L W}$

$\Delta G_{b l s}^{A B}=\gamma_{b s}^{A B}-\gamma_{b l}^{A B}-\gamma_{s l}^{A B}$

where $\gamma_{b s}$ is the interfacial tension between the bacterial surfaces and the adhesion surface, $\gamma_{b l}$ is the interfacial tension between the bacterial surfaces and the liquid, and $\gamma_{s l}$ is the interfacial tension between the adhesion surfaces and the liquid.

The free energy of adhesion between the polypropylene surface and isolated and identified bacteria from the water were determined to evaluate the influence of these factors on the thermodynamics of adhesion. The value of $\Delta \mathrm{G}$ of adhesion allows for the assessment of the thermodynamic process: if $\Delta \mathrm{G}$ adhesion is $<0$, the process is favorable; if $\Delta \mathrm{G}$ adhesion is $>0$, the process is unfavorable.

\section{Statistical analysis}

The data of physical-chemical analysis and counts of heterotrophic bacteria in purified water at the three distribution points were subjected to analysis of variance, and means were compared by Tukey's test at $5 \%$ probability using the Statistical Analysis System, version 9.1 (2006), licensed to the Federal University of Viçosa.

\section{RESULTS AND DISCUSSION}

\section{Physical-chemical and microbiological quality of drinking water purified by the purification system}

The assessment of drinking water that supplies the purification system established good physical-chemical and microbiological quality (Table II). In the period analyzed, the count of heterotrophic bacteria remained below $500 \mathrm{CFU} \mathrm{ml}^{-1}$, a limit set by the Portaria MS n ${ }^{\circ}$ 2.914 (Brasil, 2011). The average of heterotrophic bacteria count was $1.24 \log \mathrm{CFU} \mathrm{ml} l^{-1}$. Analyzing these results, it was noted that the water supply was one of the main factors responsible for good system performance.

\section{ND- Not detected}

As a fundamental guideline, potable water is the starting point for any process of purification. In addition to the pre-treatments that are used, routine monitoring of its quality must be implemented to avoid operational problems. In purification system water using reverse osmosis membranes, high levels of hardness and alkalinity provoke fouling of the membranes, reducing their efficiency and producing a higher frequency of chemical cleaning of the membranes in the devices.

The determination of $\mathrm{pH}$ is important, as it can affect the removal of salts and prevent or promote the deterioration of membranes. The $\mathrm{pH}$ of the feed water can affect the rejection of salt by the membrane because there is an optimum $\mathrm{pH}$ at which maximum rejection occurs. A higher rejection rate of certain ionic constituents, such as fluorides and bicarbonates, is eliminated by the increase of $\mathrm{pH}$ (Castanheira, 2010).

ISL is used by some manufacturers of reverse 
TABLE II - Quality of drinking water that feeds the purification system

\begin{tabular}{|c|c|c|c|c|}
\hline Parameters & Mean & $\begin{array}{l}\text { Standard } \\
\text { deviation }\end{array}$ & $\begin{array}{l}\text { Maximum } \\
\text { value }\end{array}$ & $\begin{array}{l}\text { Minimum } \\
\text { value }\end{array}$ \\
\hline Alkalinity $\left(\mathrm{mg} \mathrm{l}^{-1}\right.$ as $\left.\mathrm{CaCO}_{3}\right)$ & 20.3 & \pm 3.52 & 26.4 & 13.7 \\
\hline Heterotrophic bacteria $\left(\log \mathrm{CFU} \mathrm{mL} L^{-1}\right)$ & 1.24 & \pm 0.82 & 2.55 & ND \\
\hline Residual Free Chlorine ( $\mathrm{mg} \mathrm{L}^{-1}$ as $\mathrm{Cl}_{2}$ ) & 0.84 & \pm 0.33 & 1.83 & 0.62 \\
\hline Conductivity $\left(\mu \mathrm{S} \mathrm{cm}^{-1}\right)$ & 62.77 & \pm 7.49 & 76.18 & 52.24 \\
\hline Hardness (mg L-1 as $\mathrm{CaCO}_{3}$ ) & 20.00 & \pm 8.97 & 51.1 & 10.1 \\
\hline ISL (Langelier Saturation Index) & -3.76 & \pm 0.16 & -4.07 & -3.60 \\
\hline $\mathrm{pH}$ & 6.17 & \pm 0.34 & 7.3 & 5.7 \\
\hline Silica $\left(\mathrm{mg} \mathrm{L}^{-1}\right.$ as $\left.\mathrm{SiO}_{2}\right)$ & 15.23 & \pm 2.34 & 23 & 11 \\
\hline Total dissolved solids (mg L $\left.\mathrm{m}^{-1}\right)$ & 49.8 & \pm 30.0 & 105.5 & 17.5 \\
\hline Temperature $\left({ }^{\circ} \mathrm{C}\right)$ & 25 & \pm 2.05 & 21.3 & 27.2 \\
\hline Turbidity (uT) & 0.143 & \pm 0.03 & 0.203 & 0.100 \\
\hline
\end{tabular}

osmosis membranes to assist chemicals in the pretreatment of the feed water (Ning, Netwig, 2002). In the water purification system under study, the manufacturer recommends that the maximum value ISL should be +0.3 .

The purified water produced by the system met physical-chemical quality and microbiological quality standards in compliance with the current U.S. and EU Pharmacopoeias. The purified water was analyzed immediately after production by the system without storage in the tank, presenting $1.78 \log \mathrm{CFU} 100 \mathrm{~mL}^{-1}$ on average. The physico-chemical analyses of purified water samples from the distribution points also met the requirements and did not show differences $(p \geq 0.05)$.

The physico-chemical and microbiological analyses of purified water are of great importance for a quality product because purified water is one of the raw materials most often used in the pharmaceutical field. The quality of the purified water depends on a number of factors, such as the type of purification system and the storage and distribution procedures of the purified water that is produced. Moreover, it is necessary to constantly assess the purification procedures, including monitoring system, maintenance and cleaning.

The microbiological analysis of purified water distributed in the three points of use showed approximately the same level of bacterial contamination and did not present differences ( $p \geq 0.05)$. The average of the bacterial numbers at points I, II and III were 2.18, 2.19 and 2.20 $\log$ CFU mL $\mathrm{m}^{-1}$, respectively. In the period analyzed, the distributed purified water was kept in recirculation for $12 \mathrm{~h}$, with a mean flow velocity in the distribution loop of $0.87 \mathrm{~m} \cdot \mathrm{s}^{-1}$.

The results show that during the 40 days of analysis, for 23 days, the number of bacteria was above the allowed amount ( $2 \log \mathrm{CFU} \mathrm{mL} \mathrm{mL}^{-1}$ or $\left.100 \mathrm{CFU} \mathrm{mL}^{-1}\right)$ (recommendation of British Pharmacopoeia and USP Pharmacopoeia). The purified water produced by the system presented an acceptable microbiological level, but with storage, there was an increase in the bacterial population of approximately $2 \log$ cycles, which may be related to the presence of microbial growth and biofilms.

However, biofilms in systems for the storage and distribution of purified water are difficult to detect, inactivate, and remove. Florjanič and Kristl (2011) showed that the number of biofilm microorganisms influences the number of planktonic cells in the purified water. These authors found a high positive correlation ( $\mathrm{r}$ between 0.99 and 0.84 ) between the number of planktonic cells in purified water $\left(\mathrm{CFU} \mathrm{mL} \mathrm{m}^{-1}\right)$ and the number of heterotrophic

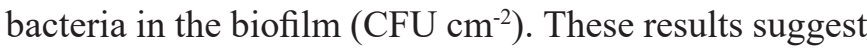
that biofilm bacteria are continuously detached to the middle of this liquid

Moreover, Boe-Hansen et al. (2002) reported that the number of planktonic bacteria is due not only to the detached bacteria of biofilm but also to the multiplication of bacteria in the liquid medium, which should also be considered

The increase of $2 \log$ cycles distributed in purified water mentioned above may be due to the multiplication of bacteria, even if the distribution system promotes water circulation with turbulence and very small concentrations of carbon and ions.

These microorganisms have adapted to strict nutrient conditions and can survive and multiply in these adverse environments. They can also induce adaptive responses to environmental stresses by expressing specific genes, 
resulting in changes in physiology, including metabolic and structural changes (Yousef, Juneja, 2003).

The storage and distribution system should be configured to avoid recontamination of the water after treatment and should be subject to a combination of monitoring techniques (WHO, 2005; Clinical and Laboratory Standards Institute, 2006).

\section{Cleaning of the water purification system}

The counts of heterotrophic bacteria in drinking water over 20 consecutive days of sampling showed a mean of $1.89 \log \mathrm{CFU} \mathrm{mL} \mathrm{m}^{-1}$; and after cleaning, the drinking water tank monitored for 20 consecutive days had a mean of $0.58 \log \mathrm{CFU} \mathrm{mL} \mathrm{m}^{-1}$, leading to a reduction in the average count of $1.32 \log \mathrm{CFU} \mathrm{mL}^{-1}$.

Prior to the sanitization of the storage tank, the swab test was performed to check the level of bacterial contamination on the surfaces in contact with purified water (Table III). To avoid possible contamination and interruption of the supply of purified water after sanitization, the swab was performed only in the area of the tank.

TABLE III - Enumeration of heterotrophic bacteria (log CFU $\mathrm{cm}^{-2}$ ) in the connections (Point III, IV and V) and storage tank of purified water

\begin{tabular}{|c|c|c|}
\hline Source & $\log _{10} C F U$ cm$^{-2 *}$ & $\begin{array}{l}\text { Standard } \\
\text { deviation }\end{array}$ \\
\hline Connection ${ }^{1}$ (Point III) & 5.09 & \pm 0.31 \\
\hline Connection ${ }^{1}$ (Point IV) & 5.30 & \pm 0.22 \\
\hline Connection ${ }^{1}$ (Point IV) & 4.80 & \pm 0.11 \\
\hline Storage tank ${ }^{2}$ & 5.63 & \pm 0.05 \\
\hline After sanitizing the tank ${ }^{3}$ & 1.29 & \pm 0.29 \\
\hline
\end{tabular}

${ }^{1}$ Connection specification in polypropylene. ${ }^{2}$ Storage tank material (polyethylene). ${ }^{3}$ Storage tank sanitization with sodium hypochlorite solution of $500 \mathrm{mg} \mathrm{L}^{-1}$ expressed CRL, $\mathrm{pH}=8$ * Average of three repetitions.

There were differences $(p<0.05)$ in the count of heterotrophic bacteria after the sanitization procedure. However, after the sanitization procedure, the microbiological quality of the purified water was assessed, and the results remained within acceptable levels for only 4 days over the 20 days of analysis. There was a gradual increase in the counts of heterotrophic bacteria up to a maximum and after reaching a plateau.

The bacteria present in the purified water may undergo proliferation and biofilm formation on the surface of the storage tank. This biofilm is difficult to remove, even with mechanical and chemical sanitizing rinse, becoming a source of contamination of the stored water. The biofilm bacteria are more resistant to antimicrobials than planktonic bacteria.

To maintain the purification of the water in the storage tanks, especially in relation to the microbiological parameters, we must consider that the material used in the distribution loop should prevent the adhesion and minimize the formation of biofilms.

\section{Identification of bacterial biodiversity isolated from the water purification system}

Table IV lists the isolated bacterial species of the water collected at various sampling points. Several isolates of Enterococcus faecium, Staphylococcus warneri, Escherichia fergusonii, Enterobacter cloacae, and Acinetobacter ssp. were previously detected in drinking water (Herson et al., 1987; Rice et al., 1991; Adcock, Saint, 2001; Olofsson, Hermansson, Elwing, 2003; Bernasconi et al., 2007; Ogier, Serror, 2008). Additionally, the species Staphylococcus warneri has been isolated from active carbon filters in water purification systems in clinical laboratories (Silva et al., 2006) and biofilms of Acinetobacter spp. were isolated from activated carbon and sand filters and water distribution points (Bifulco, Shirey, Bissonnette et al., 1989; Percival et al., 2004).

E. faecium was found in drinking water and distributed purified water, suggesting that this species passes through all stages in the purification system.

Studies of the species E. fergusonii showed its ability to form biofilms, with a larger number of adhered cells at $24{ }^{\circ} \mathrm{C}$ compared to $37{ }^{\circ} \mathrm{C}$ in minimal glucose medium relative to the other species of E. coli (Ingle et al., 2011).

The levels of nutrients present in drinking water are usually low, with organic carbon concentrations ranging from $0.05 \mathrm{mg} \mathrm{L}^{-1}$ and $12.2 \mathrm{mg} \mathrm{L}^{-1}$ and assimilable organic carbon fractions of $3 \mu \mathrm{g} \mathrm{L}^{-1}$ and $500 \mu \mathrm{g} \mathrm{L}^{-1}$. However, the concentrations of these organic materials in drinking water support the growth of various heterotrophic bacteria (Camper et al., 1991). Enterobacter cloacae is able to multiply at various concentrations of nutrients and survive chlorination (Herson et al., 1987).

Strains of the species Enterobacter cloacae and $A$. calcoaceticus produce large amounts of exopolysaccharides (Bryan, Linhardt, Daniels, 1986; Rosenberg et al., 1988; Sarafzadeh et al., 2013; Wang, Yang, Wang, 2013).

According to Rosenberg et al. (1988), strains of $A$. calcoaceticus adhere to hydrophobic surfaces, such as 
TABLE IV - Identification of bacterial species based on the analysis of 16S RNA gene

\begin{tabular}{lccc}
\hline Sampling points & Species closest BLAST search of GenBank & Code & Similarity (\%) \\
\hline Drinking water (Point 1) & Enterococcus faecium & 102790.1 & 98 \\
& Aneurinibacillus aneurinilyticus & 036798.1 & 94 \\
& Escherichia fergusonii & 074902.1 & 99 \\
Purified water (Point 2) & Acinetobacter calcoaceticus & 042387.1 & 99 \\
& Staphylococcus warneri & 102499.1 & 99 \\
& Staphylococcus warneri & 102499.1 & 99 \\
Purified water distributed (Point 3) & Enterococcus faecium & 102790.1 & 99 \\
& Enterococcus faecium & 102790.1 & 100 \\
Purified water distributed (Point 4) & Enterobacter cloacae subsp. Dissolvens & 044978.1 & 99 \\
& Enterococcus faecium & 102790.1 & 99 \\
Purified water distributed (Points 5) & Enterococcus faecium & 102790.1 & 99 \\
\hline
\end{tabular}

hydrocarbons, polystyrene and human epithelial cells. The death rates for disinfection of Acinetobacter spp. are similar to those of other heterotrophic bacteria when exposed to chlorine compounds. However, some studies have indicated that Acinetobacter can develop greater resistance to chlorine, chloramines and chlorine dioxide when grown under conditions that favor the development of biofilms (Percival et al., 2004).

The above statement was confirmed in the study by Simões, Simões and Vieira (2010) They studied the impact of microbial diversity in biofilms with six species of bacteria isolated from drinking water as it relates to their resistance to disinfection with sodium hypochlorite. Among these species, the A. calcoaceticus biofilm was susceptible to disinfection and achieved total inactivation; however, its presence in multi-species biofilms increased its resistance to disinfection.

A. calcoaceticus species also showed the ability to aggregate strongly compared to other bacteria studied, and their presence in a multi-species community represents an advantage in colonization. This adhesion mechanism is highly specific and transmits advantages to microorganisms, including transfer of chemical signals, exchange of genetic information, protection against adverse environmental conditions, metabolic cooperation between different species and cell differentiation in some population (Simões, Simões, Vieira, 2008).

\section{Prediction of the adhesion of bacterial isolates to polypropylene}

Cells of different species in drinking water and purified water showed a value of $\Delta \mathrm{G}^{\mathrm{TOT}}>0$, considered to be hydrophilic according to Van Oss (1995). Additionally, the polypropylene surface is considered to be hydrophilic due to the value of $\Delta \mathrm{G}^{\mathrm{TOT}}>0$ (Table $\mathrm{V}$ ).

TABLE V - Values of the apolar $\left(\Delta G_{S A S}^{L W}\right)$ and polar $\left(\Delta G_{S A S}^{A B}\right)$ components and of the total free energy of interaction $\left(\Delta G_{S A S}^{T O T}\right)$ the isolated bacteria and the surface

\begin{tabular}{lccc}
\hline \multirow{2}{*}{ Surfaces } & \multicolumn{3}{c}{ Free energy of interaction } \\
& \multicolumn{3}{c}{$\left(\mathrm{mJ} \mathrm{m}^{-2}\right)$} \\
\cline { 2 - 4 } & $\Delta G_{S A S}^{L W}$ & $\Delta G_{S A S}^{A B}$ & $\Delta G_{S A S}^{T O T}$ \\
\hline Polypropylene & -3.61 & 16.76 & 13.11 \\
A. aneurinilyticus & -0.32 & 36.87 & 36.51 \\
Escherichia fergusonii & 0.00 & 21.22 & 21.25 \\
Enterobacter cloacae & -1.19 & 29.77 & 28.57 \\
Enterococcus faecium & -1.27 & 28.45 & 27.18 \\
Staphylococcus warneri & -2.98 & 7.03 & 4.05 \\
Acinetobacter calcoaceticus & -0.16 & 26.06 & 25.90 \\
\hline
\end{tabular}

The strain of $A$. calcoaceticus was also considered to be hydrophilic according to research performed by Van der Mei, Bos and Busscher (1998). However, the numerical values of hydrophobic interactions of free energy should not be compared to bacteria within the same species because there are differences in measurements between contact angles in water (Simões et al., 2007).

To predict the ability of microorganisms to adhere to the surface, the total free energy between the adhesion of microorganisms and the material of the distribution loop when immersed in water was calculated (Table VI). The values of $\Delta \mathrm{G}$ adhesion allow 
us to evaluate the thermodynamics of adhesion, which are thermodynamically favorable when $\Delta \mathrm{G}$ adhesion $<$ 0 , suggesting that adhesion occurs spontaneously, with unfavorable adhesion when $\Delta \mathrm{G}$ adhesion $>0$.

TABLE VI - Values of free energy of adhesion ( $\Delta G$ adhesion) between the isolated bacterial cells (b) and the surface of the loop distribution (polypropylene) $(s)$ in an aqueous medium $(l)$

\begin{tabular}{lc}
\hline Surface/Bacteria & $\begin{array}{c}\text { Total energy of } \\
\text { interaction free } \\
\left(\mathrm{mJ} \mathrm{m}^{-2}\right)\end{array}$ \\
\cline { 2 - 2 } & \begin{tabular}{c}
$\Delta G$ adhesion \\
\hline Polypropylene_A. aneurinilyticus
\end{tabular} \\
Polypropylene_Escherichia fergusonii & 28.20 \\
Polypropylene_Enterobacter cloacae & 23.73 \\
Polypropylene_Enterococcus faecium & 22.72 \\
Polypropylene_Staphylococcus warneri & 19.00 \\
Polypropylene_A. calcoaceticus & 24.40 \\
\hline
\end{tabular}

It was observed that the adhesion between the polypropylene and the isolated bacteria was thermodynamically unfavorable. According to Van Oss (1995), it is well known that an aqueous environment favors adhesion to hydrophobic surfaces due to the expulsion of water. However, adhesion between hydrophilic surfaces can occur.

The prediction of adhesion potential based on physicochemical properties provides useful information about the possible microbial behavior under actual conditions (Simões et al., 2007). In this work, only one thermodynamic factor was studied, which indicated that the adhesion is thermodynamically unfavorable; the adhesion and the formation of biofilms of the species identified on the surface cannot be predicted because the thermodynamic theory does not consider the microbiological aspects of the adhesion.

However, the results of prediction thermodynamics were consistent with the counts of heterotrophic bacteria in polypropylene surfaces (distribution loop), which reached values of approximately $5 \log \mathrm{CFU} \cdot \mathrm{cm}^{-2}$. If the thermodynamics were favorable to the adhesion of bacteria to the surface, this count would be much higher

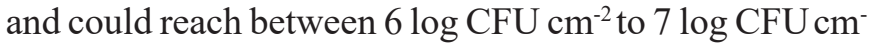
${ }^{2}$. Although these results are consistent, it is important to note that these values for a surface that comes into contact with the purified water can influence the microbiological quality.

Several factors can influence the adhesion of bacteria to surfaces, such as the hydrophobicity of the cells and cellular appendages that contribute to increased adherence (Pang et al., 2005; Herzberg, Elimelech, 2007). Many of the identified bacterial species have cellular appendages, which can mediate the adhesion process; for example, the genus Acinetobacter presents polysaccharide capsules and fimbriae (Towner, 2002; Percival et al., 2004). Extracellular structures, such as pili, fimbriae, flagella and exopolysaccharides, can liaise between the cell and the adhesion substrate, neutralizing electrostatic repulsion (Simões, Simões, Vieira, 2010).

Predictions based solely on the physical-chemical properties of the surface and on thermodynamic approaches only provide information on the understanding of the adhesion process and the formation of biofilms. Furthermore, multi-species interactions prevail in the environment, and the strongly adherent bacteria may play a key role in the primary colonization of surfaces with other microorganisms.

\section{CONCLUSION}

The water purification system monitored in this case study, which has been in operation for two years, produces water that meets the physico-chemical and microbiological quality requirements within the criteria established by pharmacopeia. However, with storage, the distributed purified water exhibits microbiological levels above the permitted standards because they exceeded the maximum of $2 \log \mathrm{CFU} \cdot \mathrm{mL}^{-1}$, which may compromise the analytical results of some research laboratories.

The surfaces of the bacteria isolated in the samples from the purification system and the surface of the water distribution loop are hydrophilic and thermodynamically unfavorable for adhesion.

The results of the thermodynamic predictions were consistent with the counts of heterotrophic bacteria of the polypropylene surface (distribution loop), which reached approximate values of $5 \log _{10} \mathrm{CFU} \cdot \mathrm{cm}^{-2}$

\section{AKNOWLEDGEMENTS}

The authors would like to thanks the financial support provided by the Conselho Nacional de Desenvolvimento Científico e Tecnológico (CNPq/Brazil) and Fundação de Amparo à Pesquisa do Estado de Minas Gerais (FAPEMIG/MG). 


\section{REFERENCES}

ABSOLOM, D.R.; LAMBERTI, F.V; POLICOVA, Z.; ZINGG, W.; VAN OSS, C.J.; NEUMANN, A.W. Surface thermodynamics of bacterial adhesion. Appl. Environ. Microbiol., v.46, n.1, p.90-97, 1983.

ADCOCK, P.W.; SAINT, C.P. Development of glucosidase agar for the confirmation of water-borne Enterococcus. Water Res., v.35, n.17, p.4243-4246, 2001.

\section{AMERICAN PUBLIC HEALTH ASSOCIATION. Standard} methods for the examination of water and wastewater. 21.ed. Washington, DC: American Public Health Association, 2005. $1368 \mathrm{p}$.

AMERICAN SOCIETY FOR TESTING AND MATERIAL. Standard Specification for Reagent Water, Document D1193-91. West Conshohocken, PA: American Society for Testing and Materials (ASTM), 1991. $6 \mathrm{p}$.

BAKER, G.C.; SMITH, J.J.; COWAN, D.A. Review and reanalysis of domain-specific $16 \mathrm{~S}$ primers. J. Microbiol. Meth., v.55, n.3, p.541-555, 2003.

BERESCHENKO, L.A.; STAMS, A.J.M.; EUVERINK, G.J.W.; VAN LOOSDRECHT, M.C.M. Biofilm formation on reverse osmosis membranes is initiated and dominated by Sphingomonas spp. Appl. Environ. Microbiol., v.76, n.8, p.2623-2632, 2010.

BERNASCONI, C.; VOLPONI, G.; PICOZZI, C.; FOSCHINO, R. Use of the tna operon as a new molecular target for Escherichia coli detection. Appl. Environ. Microbiol., v.73, n.19, p.6321-6325, 2007.

BIFULCO, J.M.; SHIREY, J.J.; BISSONNETTE, G.K. Detection of Acinetobacter spp. in rural drinking water supplies. Appl. Environ. Microbiol., v.55, n.9, p.2214-2219, 1989.

BOE-HANSEN, R.; ALBRECHTSEN, H.-J.; ARVIN, E.; JØRGENSEN, C. Bulk water phase and biofilm growth in drinking water at low nutrient conditions. Water Res., v.36, n.18, p.4477-4486, 2002.

BRASIL. Ministério da Saúde. Portaria no 2.914 de 12 de dezembro de 2011. Dispõe sobre os procedimentos de controle e de vigilância da qualidade da água para consumo e seu padrão de potabilidade. Diário Oficial da União, Brasília, Seção 1, 14 dez. 2011.
BRITISH PHARMACOPOEIA. Purified Water. In: British Pharmacopoeia 2009. [s.1: s.n.], 2009. p.418-420.

BRYAN, B.A.; LINHARDT, R.J.; DANIELS, L. Variation in composition and yield of exopolysaccharides produced by Klebsiella sp. strain K32 and Acinetobacter calcoaceticus BD4. Appl. Environ. Microbiol., v.51, n.6, p.1304-1308, 1986.

BUSSCHER, H.; WEERKAMP, A.; VANDERMEI, H.; VANPELT, A.; DEJONG, H.; ARENDS, J. Measurement of the surface free-energy of bacterial-cell surfaces and its relevance for adhesion. Appl. Environ. Microbiol., v.48, n.5, p.980-983, 1984.

CAMPER, A.K; MCFETERS, G.A; CHRACKLINS, W.G.; JONES, W.L. Growth kinetics of coliform bacteria under conditions relevant drinking water distribution systems to. Appl. Environ.l Microbiol., v.57, n.8, p.2233-2239, 1991.

CASTANHEIRA, A.A. Aplicación de membrana de nanofiltración para eliminar disruptores endocrinos en la potabilización del agua. Catalunya: Universitat Politecnica de Catalunya, 2010.

CHAKRAVORTY, S.; HELB, D.; BURDAY, M.; CONNELL, N.; ALLAND, D.A detailed analysis of $16 \mathrm{~S}$ ribosomal RNA gene segments for the diagnosis of pathogenic bacteria. $J$. Microbiol. Meth., v.69, n.2, p.330-9, 2007.

CHRISTIE-OLEZA, J.A.; PINA-VILLALONGA, J.M.; BOSCH, R.; NOGALES, B.; ARMENGAUD, J. Comparative proteogenomics of twelve roseobacter exoproteomes reveals different adaptive strategies among these marine bacteria. Mol. Cell. Proteomics, v.11, n.2, p.M111.013110-M111.013110, 2012.

CLINICALAND LABORATORY STANDARDS INSTITUTE. Preparation and testing of reagent water in the clinical laboratory. Wayne, PA: Clinical and Laboratory Standards Institute (CLSI). Document C3-A4, 2006.

FOOD AND DRUG ADMINISTRATION. FDA. Inspection Guide - Water for Pharmacuetical Use. Silver Spring, MD: FDA, 1986.

FLORJANIČ, M.; KRISTL, J. The control of biofilm formation by hydrodynamics of purified water in industrial distribution system. Int. J. Pharm., v.405, n.1-2, p.16-22, 2011. 
HERSON, D.S.; MCGONIGLE, B.; PAYER, M.A.; BAKER, K.H.Attachment as a factor in the protection of Enterobacter cloacae from chlorination. Appl. Environ. Microbiol., v.53, n.5, p.1178-1180, 1987.

HERZBERG, M.; ELIMELECH, M. Biofouling of reverse osmosis membranes: Role of biofilm-enhanced osmotic pressure. J. Memb. Sci., v.295, n.1-2, p.11-20, 2007.

INGLE, D.J.; CLERMONT, O.; SKURNIK, D.; DENAMUR, E.; WALK, S.T.; GORDON, D.M. Biofilm formation by and thermal niche and virulence characteristics of Escherichia spp. Appl. Environ. Microbiol., v.77, n.8, p.2695-2700, 2011.

KIM, M.; MORRISON, M.; YU, Z. Evaluation of different partial 16S rRNA gene sequence regions for phylogenetic analysis of microbiomes. J. Microbiol. Meth., v.84, n.1, p.81-87, 2011.

MCFETERS, G.A.; BROADAWAY, S.C.; PYLE, B.H.; EGOZY, Y. Distribution of bacteria within operating laboratory water purification systems. Appl. Environ. Microbiol., v.59, n.5, p.1410-1415, 1993

MEINDERS, J.M.; VAN DER MEI, H.C.; BUSSCHER, H.J. Deposition Efficiency and Reversibility of Bacterial Adhesion under Flow. J. Colloid Interface Sci., v.176, n.2, p.329-341, 1995.

NING, R.Y.; NETWIG, J.P. Complete elimination of acid injection in reverse osmosis plants. Desalination, v.143, n.1, p.29-34, 2002.

OGIER, J.-C.; SERROR, P. Safety assessment of dairy microorganisms: the Enterococcus genus. Int. J. Food Microbiol., v.126, n.3, p.291-301, 2008.

OLOFSSON, A.; HERMANSSON, M.; ELWING, H. N-AcetylL-Cysteine affects growth, extracellular polysaccharide production, and bacterial biofilm formation on solid surfaces. Appl. Environ. Microbiol., v.69, n.8, p.4814-4822, 2003.

PANG, C.M.; HONG, P.; GUO, H.; LIU, W.T. Biofilm formation characteristics of bacterial isolates retrieved from a reverse osmosis membrane. Environ. Sci. Technol., v.39, n.19, p.7541-7550, 2005
PENNA, V.T.C.; MARTINS, S.A.M.; MAZZOLA, P.G. Identification of bacteria in drinking and purified water during the monitoring of a typical water purification system. BMC Public Health, v.2, p.13, 2002.

PERCIVAL, S.; CHALMERS, R.; EMBREY, M.; HUNTER, P.; SELLWOOD, J.; WYN-JONES, P. Microbiology of waterborne diseases. [s.1.]: Elsevier, 2004. 480p.

PUBLIC HEALTH PROTECTION. Public health engeneering guideline: disinfection of water storage facilites. [s.1.]: PHP, 2009.

RICE, E.W.; ALLEN, M.J.; BRENNER, D.J.; EDBERG, S.C. Assay for $\beta$-glucuronidase in species of the genus Escherichia and its applications for drinking-water analysis. Appl. Environ. Microbiol., v.57, n.2, p.592-593, 1991.

RIDGWAY, H.F.; RIGBY, M.G.; ARGO, D.G. Adhesion of a Mycobacterium sp. to cellulose diacetate membranes used in reverse osmosis. Appl. Environ. Microbiol., v.47, n.1, p.61-67, 1984.

ROSENBERG, E.; RUBINOVITZ, C.; GOTTliEB, A; ROSENHAK, S.; RON, E.Z. Production of biodispersan by Acinetobacter calcoaceticus A2. Appl. Environ. Microbiol., v.54, n.2, p.317-322, 1988.

SARAFZADEH, P.; HEZAVE, A.Z.; RAVANBAKHSH, M.; NIAZI, A.; AYATOLLAHI, S. Enterobacter cloacae as biosurfactant producing bacterium: differentiating its effects on interfacial tension and wettability alteration Mechanisms for oil recovery during MEOR process. Colloids Surf. B: Biointerf., v.105, p.223-9, 2013.

SILVA, C.H.P.M; LINS, A.P.; CRUZ, C.S.O; GREENBERG, W.; STEWART, T. Caracterização dos biofilmes formados em filtros de carvão ativado de sistemas de purificação de água em laboratórios clínicos. $R B A C$, v.38, n.4, p.243-253, 2006.

SIMÕES, L.C.; SIM̃OES, M.; OLIVEIRA, R.; VIEIRA, M.J. Potential of the adhesion of bacteria isolated from drinking water to materials. J. Basic Microbiol., v.47, n.2, p.174-183, 2007.

SIMÕES, L.C.; SIMÕES, M.; VIEIRA, M.J. Intergeneric coaggregation among drinking water bacteria: Evidence of a role for Acinetobacter calcoaceticus as a bridging bacterium. Appl. Environ. Microbiol., v.74, n.4, p.1259$1263,2008$. 
SIMÕES, L.C.; SIMÕES, M.; VIEIRA, M.J. Influence of the diversity of bacterial isolates from drinking water on resistance of biofilms to disinfection. Appl. Environ. Microbiol., v.76, n.19, p.6673-6679, 2010.

SOHRABI, M.R.; MADAENI, S.S.; KHOSRAVI, M.; GHAEDI, A.M. Chemical cleaning of reverse osmosis and nanofiltration membranes fouled by licorice aqueous solutions. Desalination, v.267, n.1, p.93-100, 2011.

TOWNER, J.K. Molecular medical microbiology. [s.1.]: Elsevier, 2002. v.2.

VAN DER MEI, H.C.; BOS, R.; BUSSCHER, H.J. A reference guide to microbial cell surface hydrophobicity based on contact angles. Coll. Surf. B: Biointerf., v.11, n.4, p.213$221,1998$.

VAN LOOSDRECHT, M.C.M.; NORDE, W.; LYKLEMA, J.; ZEHNDER, A.J.B. Hydrophobic and electrostatic parameters in bacterial adhesion - Dedicated to Werner Stumm for his 65th birthday. Aquat. Sci., v.52, n.1, p.103$114,1990$.

VAN OSS, C.J. Energetics of cell-cell and cell -biopolymer interactions. Cell Biophys., v.14, p.1-16, 1989.
VAN OSS, C.J. Interfacial forces in aqueous media. Powder Technol., v.82, n.2, p.209-210, 1995.

WANG, F.; YANG, H.; WANG, Y. Structure characterization of a fucose-containing exopolysaccharide produced by Enterobacter cloacae Z0206. Carbohydr. Polym., v.92, n.1, p.503-9, 2013.

WORLD HEALTH ORGANIZATION. WHO good manufacturing practices : water for pharmaceutical use, Annex 3 WHO Technical Report Series. Geneva: WHO, 2005.

YOUSEF, A.E.; JUNEJA, V.K. Microbial stress adaptation and food safety. Danvers, MA: CRC Press, 2003.

ZHANG, H.; HUANG, T.; LIU, T. Sediment enzyme activities and microbial community diversity in an oligotrophic drinking water reservoir, Eastern China. PLoS ONE, v.8, n.10, e78571, 2013.

Received for publication on $15^{\text {th }}$ April 2016 Accepted for publication on $17^{\text {th }}$ January 2017 